\title{
THEORETICAL SYNTAX IN SECOND LANGUAGE ACQUISITION RESEARCH AND IN SECOND LANGUAGE CLASSROOM RESEARCH
}

\author{
Marianna Visser \\ Department of African Languages \\ University of Stellenbosch
}

\section{INTRODUCTION}

Second language teaching practicioners have tried to a greater or lesser extent in the past to apply the insights of linguistic theories to teaching methodology and curriculum design. A diverse range of sub-disciplines within the global field of linguistics, such as sociolinguistics, psycholinguistics, discourse theory and pragmatics are generally considered to be relevant. This gives evidence of the widely-held view that second language acquisition is an extremely complex phenomenon of a multi-faceted nature. (See the Appendix to this paper for a list of some recent works within the general field of second-language learning and teaching.) The purpose of this paper is to review the issues that are generally acknowledged to be relevant to theories of second language acquisition, to outline the nature of second language classroom research, and in particular to deal with the insights that the Universal Grammar approach can provide as regards the development of the second language grammar of learners. The Universal Grammar perspective of second language acquisition will then be discussed with respect to its implications for teaching practice, and more specifically for the role of grammar in instruction and input.

\section{THE MULTI-FACETED NATURE OF SECOND LANGUAGE ACQUISITION}

There is general agreement on the characterisation of language proficiency required for communication as proposed by Canale and Swain (1980). They identify three interacting factors of language proficiency (or competence as they refer to it), namely (i) grammatical competence, which entails the mastery of formal structural properties of language; (ii) sociolinguistic competence, which entails the ability to use appropriate utterances with respect to both meaning and form; and (iii) discourse competence, which entails the ability to construct a coherent and cohesive spoken or written text. These three broad properties of language profiency have subsequently been considered for the purpose of developing theories of second language acquisition, in addition to numerous other considerations concerning the process of second language learning. 
Ellis (1985) identifies the following key issues which must be taken into account in a theory of second language acquisition:

(i) The role of the first language: This factor relates to the issue of how the first language influence second language acquisition.

(ii) The possible natural developmental sequence of language structure (grammar).

(iii) Contextual variation: This aspect includes factors such as naturalistic versus classroom language learners, and learner language (including types of errors, and interlanguage).

(iv) Individual learner differences: This aspect includes factors such as age, aptitude, cognitive style, motivation and personality.

(v) The role of input: This issue relates to the question of whether input can shape and control learning, or whether it simply serves as a trigger.

(vi) Learner processes: Ellis states that two possible explanations may be given. Firstly the Universal Grammar explanation, according to which language acquisition is possible because of the innate mental knowledge that humans have of principles and rules of language, and which, with experience, enables them to acquire the grammars of specific languages. It is postulated that human beings have a language-specific cognitive faculty.

Secondly, Ellis considers the possibility that second language acquisition can result from the use of general cognitive strategies which are part of the learners' procedural knowledge, and which are used in other forms of learning. These strategies are of ten referred to as learner strategies.

(vii) The role of formal instruction (including the role of grammar): Ellis points out that this is a factor which is of central importance to the teacher. Two aspects may be considered, namely the effect that instruction has on the sequence or 'route' of learning and on the rate of learning. Studies suggest that the natural sequence of the development of the second language grammar cannot be changed by instruction but that the rate of acquisition increases. Thus instruction can enhance second language acquisition by accelerating the whole process. 
Ellis invokes the above interrelated factors for proposing a framework for investigating second language acquisition.

Spolsky (1989) outlines a framework for a general theory of second language learning that consists of a set of preference conditions which may combine in a more general classification of factors. He views the process of second language acquisition as a predictive one, posing the question: What are the chances that learners will acquire a second language, given that the proposed conditions obtain. The range of conditions which he formulates relates to the aspects considered by Ellis, as outlined above. Spolsky specifies each of these conditions as necessary, graded or typical. Necessary conditions are conditions without which learning is impossible; graded conditions reflect a relation between the extent to which a condition is met and the nature of the outcome; typicality conditions are conditions which apply typically, but not necessarily. This organisation accommodates the possibility of a varied but limited set of alternative paths to various outcomes. The conditions for second language acquisition identified by Spolsky can broadly be classified as relating to the following aspects:

(i) Knowledge of language and knowledge of how to use it.

(ii) The characterisation of language proficiency.

(iii) The psycholinguistic basis for second language learning, including biological and neurophysiological factors.

(iv) Individual differences in cognitive capacities and personality.

(v) Previous knowledge: This factor refers to the knowledge of the first language and the way it may be seen as setting conditions for second language learning.

(vi) The social context: This factor relates to the social environment in which second languages are learned, and the relationship between social context and individual psychological properties such as attitude and motivation.

(vii) Conditions for second language learning in informal (naturalistic) and formal (classroom) learning situations.

Ellis (1990) postulates an integrated theory of instructed second language learning. He investigates classroom (instructed) language learning and the relationship between classroom interaction and language learning. His theory invokes insights from cognitive learning theory as well as psycholinguistic factors, including Universal Grammar, which 
he assumes, are responsible for the way in which language knowledge is reflected in the learner's interlanguage.

The theoretical frameworks for second language acquisition by Ellis and Spolsky as outlined above can be described as all-inclusive frameworks, in the sense that they attempt to account for the whole range of diverse factors that are relevant to second language learning. McLauglin (1987), on the other hand, argues that more limited and more specific theories are needed, rather than a general all-inclusive theory, for the reason that a certain issue can be explored in more depth in a theory which has as its domain of inquiry a more restricted issue. McLaughlin advances an integrated approach to second language acquisition that incorporates both the more creative aspects of language learning and the more cognitive aspects that are susceptable to guidance and instruction. He maintains that there are ways of accommodating acquisitional sequences based on innate unversal linguistic processes within a more general cognitive perspective. Seliger (1988) expresses the opinion that no one study or theory will provide answers to all questions concerning second language acquisition. In accordance with this view the role of the Universal Grammar approach to the development of grammars in second language acquisition will be discussed below. First, however, the matters of concern for second language classroom research are reviewed.

\section{SECOND LANGUAGE CLASSROOM RESEARCH}

The actual processes, procedures, activities and techniques of teachers and learners within the classroom constitute the field of interest for second language classroom research. In addition, methodological issues relating to test design and statistics relating to classroom research are explored. Chaudron (1986) views the following phenomena as important:

(i) Teacher talk in second language classtooms: This factor is concerned with matters such as the type and amount of teacher talk, and modifications in teacher speech as regards speech rate, syntax, vocabulary, discourse and phonology.

(ii) Learner behavior in second language classrooms: This factor is concerned with matters such as learner language production, input generation, interaction between learners and learner strategies. 
(iii) Teacher and learner interaction in second language classrooms: This aspect relates to factors such as question behaviour, differentiation of teacher speech to learners' choice, and feedback.

(iv) Learning outcomes: This aspect deal with matters such as learner comprehension and production, formal language instruction, that is, focus on language structure or grammar instruction, learner production, interaction and strategies.

Chaudron suggests that much more research needs to be done to determine what facilitates learners' target language development. He emphasises that research which is based on a well-articulated theory is more powerful as a guide to further research.

Allwright and Bailey (1991) deal with the issue of receptivity in the second language classroom in addition to the above aspects. Receptivity can be explored with regard to the teaching material, the teacher, and fellow learners. They point out that the concept of the exploratory teacher becomes a crucial one in the context of classroom research. The exploratory teacher is in fact teacher-researcher. He or she can enhance the outcome of learners by knowing about the findings and results of theoretical research on second language acquisition. In this way the exploratory teacher can improve the success of learners and contribute to the knowledge about classroom issues. Allwright and Bailey view the exploratory teacher as the means to more effective teaching.

Nunan (1991) is also concerned with the role of the teacher-researcher. He maintains that teachers can become more actively involved in the research process. The development of skills in observing and documenting classroom action and interaction is of central importance for classroom research, particularly if a research orientation is adopted. Nunan asserts that such an orientation applies a new role for the teacher. It is at variance with the view of the teacher as a passive recipient of someone else's curriculum or teaching methodology. According to Nunan, the adoption of this orientation is therefore incompatible with the methods approach to language teaching with its concern with the one best way, that is, the method that will work for every conceivable learner in every conceivable learning situation, and which impose prescriptions as to what teachers and learners should do in the language classroom. He argues that the teacher-researcher is rather concerned with the investigation of variable issues relating to classroom activities. The notion of the teacher-researcher implies that teachers can find, exploit and enhance their own best ways of teaching while applying and extending research ideas. Nunan emphasises that there is scope for teachers to modify and adapt the syllabuses, methodology and teaching materials with which they work, even when they have to work with clearly articulated syllabuses and curriculum specifications. 

MENT OF GRAMMARS IN SECOND LANGUAGE ACQUISITION

The theory of generative grammar postulates that knowledge of language can be represented in terms of structural configurations. One of the basic assumptions of this theory is that the ability which human beings have to acquire a language is biologically determined: All human beings are genetically endowed with a language-specific mental faculty, referred to as the language faculty. An important distinction that is made concerns the notions of competence and performance. Competence refers to the unconscious knowledge that a person has of the abstract rules and principles of language, while pcrformance refers to the actual use of a language. Universal Grammar is the set of principles, rules and parameters that constitute the initial state knowledge of the language learner and which constrains the form of grammars. Thus, the principles of Universal Grammar entail a set of properties with certain parameters, that is, variables of options. Janguage acquisition can be viewed as the process whereby the learner sets the values of the parameters of the Universal Grammar principles. The different values for parameters are called parameter settings. Thus the grammar of a language consists of the set of values it assigns to various parameters. Experience (i.e. exposure to language data) is a prerequisite for parameter setting.

An example of a Universal Grammar parameter that has been the subject of much research in second language acquisition is the pro-drop (or null subject) parameter which allows the subject NP of certain languages (e.g. the Romance languages) to be phonetically empty. This option is often associated with rich verb inflection, in particular subject-verb agreement. Chomsky (1981) states that the null subject phenomenon belongs to a cluster of properties are associated, including free NP subject inversion in simple sentences, and empty resumptive pronominals in relative clauses. In the African languages, which are highly inflected languages, the null subject paramteter has been extended to all syntactic positions available to NP (including object and prepositional object) so that the null head parameter can be posited which, in its simplest form, can be formalised as: The head of an NP may be phonetically empty or null.

The theory of generative grammar is concerned with the question of how a child can acquire a language in such a relatively short time, given the deficient input. This is referred to as the 'projection problem' of the child first language learner. The projection problem can be explained by assuming that the child is endowed with Universal Grammar that comprises a highly abstract set of principles and rules of language. 
A central distinction is made between core and peripheral grammar. Core grammar refers to the language properties that have been acquired by the child through the interaction of the Universal Grammar with a specific language environment. In addition, each language also has properties that are not constrained by Universal Grammar. These properties constitute the peripheral grammar. Peripheral properties include, among others, elements of a language that have been borrowed from other languages. Another distinction made with respect to Universal Grammar is that between unmarked and marked properties. Unmarked properties refer to those rules and principles that represent the regular or normal instances, and marked properties refer to those rules and principles that represent the exceptional or irregular instances. The rules and principles of the core grammar are generally assumed to be unmarked, those of the peripheral grammar are marked.

Second-language researches who adopt the Universal Grammar approach assume that the principles and parameters of Universal Grammar are still available to the adult second-language learner. This vicw has important implications for properties of learner language, specifically for how interlanguage development and transfer are investigated. These researchers assume that the second language adult learner has a grammar that is systematic in its own right, and is distinct from both the learner's first language and the second language which he or she is learning. Thus Universal Grammar theory assumes that all grammars, interim or final, reflect principles of Universal Grammar. Second language learners' grammar is constrained in the same way as first language learners' grammars. Studies from the Universal Grammar perspective on the development of grammars in second language acquisition provides evidence in support of the view that interlanguages reflect the principles of Universal Grammar and that types of errors that learners make are constrained by universal principles. Apparent violations in this regard may be attributed to the learner's channel capacity, that is, the learner's ability to process information, memory limitations, and so on.

McLaughlin (1987) identifies four main considerations which have motivated the application of the Universal Grammar theory to the domain of the development of grammars in second language acquisition, as put forth by researchers, notably White.

(i) A need existed for a sufficiently well-articulated linguistic theory to describe the complex, structural characteristics of interlanguages.

(ii) It was realised that adult second language learners, like child first language learners, are confronted with a projection problem in that they have to acquire a complex grammar on the basis of deficient data. It is assumed in accordance with generative grammar, that the learners grammatical knowledge cannot be 
accounted for by the input data alone, for three main reasons. First, some structures are considerably rare and marginal and hence it is unlikely that learners will obtain sufficient exposure to them. Second, negative feedback (by way of correction, identification of error, etc.) is required for incorrect hypotheses made by the learner to be dismissed, but such feedback usually does not occur. Correction cannot be ruled out as source of evidence in the classroom: teachers use it frequently and learners often request it. However, correction is unlikely to occur of the types of errors needed to acquire Universal Grammar principles and parameters some of which are highly abstract and do not reflect surface properties of the language. As adult learners manage to acquire a second language without this type of correction Universal Grammar must be available to them. Thus it is assumed that, like child first language learners, adult second language learners have the mental ability to acquire the central structural properties of the second language and this mental ability is employed in constructing the grammar of the language they are iedrning.

(iii) The development of the principles and parameters paradigm in generative grammar enables a more precise and well-defined investigation of language differences - including differences between the first language and the second language of learners.

Cook (1988) observes that if second language learners possess knowledge they could not have acquired by evidence (input data) the explanation must be given in terms of an inherent mental ability. This is referred to as the poverty of stimulus argument in support of the view of the Universal Grammar perspective on the development of grammars. Cook points out that this argurnent has led to the conclusion the second language learners know properties of grammar which they could not have acquired from the environment. However, this view has to be qualified since the terminal state version of the second language of the learner is different from the steady state language of the first language learner in that the second language learner's acquisition is characteristically incomplete.

Cook states that three possible models can be considered as regards the role of Universal Grammar in the development of grammars in second language acquisition.

(i) The direct access model: According to this model second language learners may use the principles of Universal Grammar and set the parameters for the second language without any reference to their first language. 
(ii) The indirect access model: In accordance with this model, learners' first language instantiation of Universal Grammar serves as a kind of surrogate, and these first language principles and parameters may be reflected in the second language.

(iii) The no-access model: In this model, second language competence is not related to the language faculty, hence Universal Grammar. Cook states that this model can, however, be set aside because of the intrinsic differences of the language faculty from other cognitive faculties. The reasons for access of adult second language learners to Universal Grammar discussed above are sufficient support to exclude this model.

Thus the issue concerning the role of Universal Grammar in second language acquisition relates to the two remaining models, the Direct access model, of which notably White is a proponent, and the indircct access model of which Clahsen is a proponent. Research seems to suggest increasingly that the indirect access model is correct: second language learners use their first language instantiations of Universal Grammar as a surrogate projection device to second language acquisition. In addition the precise role of general cognitive learning strategies and psychological processes are explored by many researcher who argue that these factors also play a significant role in the development of learners' grammars in second language acquisition. Certain methodological problems as regards grammaticality judgement tests have yet to be resolved as well as the problem of precisely how Universal Grammar properties, general cognitive strategies and psychological processes of computation relate to one another.

\section{IMPLICATIONS OF THE UNIVERSAL GRAMMAR PERSPECTIVE FOR TEACHING PRACTICE: LANGUAGE STRUCTURES AND INPUT}

Several recent studies have given evidence for the effectiveness of focus on form in the classroom as a means to increase success in second language acquisition. Evidence to this effect is given in the studies of Lightbown and Spada (1990), Doughty (1991) and Day and Shapson (1991), among others. The strategy of focus on form in second language teaching methodology entails that the teaching practicioner deliberately deals with the language structure, that is syntactic and morphological properties, of the language in the classroom. This can be done in several ways and need not always entail explicit grammar teaching. An interesting strategy, called consciousness raising which was originally introduced by Sharwood-Smith can be employed by teachers for the purpose of dealing 
with language structure. This strategy is discussed in more detail below. It is important to distinguish between the teaching of grammar, on the one hand, and grammar-based teaching, on the other. Grammar-based teaching deals with language structure as an end in itself. On the other hand, the teaching of grammar can be a component in communicative language teaching. Since the communicative approach to second language teaching is widely adopted throughout the world I will deal with the question of the teaching of language structure with this approach in mind. Studies by well-known researchers on curriculum design for communicative language teaching such as Yalden (1987) and Nunan (1989) include a component for teaching of language structure in their curriculum models. The teaching of grammar is thus not viewed as conflicting with the communicative approach: it can and must be accommodated, provided that it is done within a meaningful context. The idea of integrating form and function is crucial in this regard. Canale and Swain (1988) state that communicative competence is not best served by syllabi that focus purely on functional aspects at the expense of grammatical features.

I take the position that focus on form can deal in a principled way with problems of language acquisition resulting from differences in parameter settings between the leaner's first language and the second language. White also advances this view and proposes that differential consciousness raising strategies will facilitate acquisition. Rutherford and Sharwood-Smith (1988) define the concept of consciousness raising beyond metalinguistic awareness as a source of explicit knowledge of grammar to include more non-overt sources of implicit linguistic knowledge. Consciousness raising is thus viewed as a means to knowledge of parametric variation across languages, and to principles and constraints of language in general. Studies invoking this approach include those of White, Flynn and Liceras (see relevant sources in bibliography).

Rutherford and Sharwood-Smith point out that the well-articulated principles and parameters framework of generative grammar enables a kind of a contrastive analysis between the learners' first language and their second language at the level of Universal Grammar properties, a very different level of analysis from the kind of contrastive analysis based on a descriptive contrast of the surface properties of language structure, as has been done in the past. Thus it is now possible to compare languages in terms of the differential application across languages of universal principles. This approach has interesting implications for second language teaching practice, in particular with respect to the idea of consciousness raising in input and the introduction of a pedagogical grammar. Rutherford and Sharwood-Smith relates the notion of consciousness raising, which they define as the utilisation of various means of drawing attention to structural features of the second language to their hypothesis of pedagogical grammar. This hypothesis holds that instructional techniques that heighten consciousness raising are 
likely to improve the rate of second language acquisition relative to non-interventionist context. Contrastive research is therefore now possible within a theoretically principled framework, a fact which establishes its value for language pedagogy and supports the emprical testing of the pedagogical grammar hypothesis. Rutherford and SharwoodSmith argue that the serious consideration of the pedagogical grammar hypothesis as a set of empirical questions concerning the introduction of differential consciousness raising in teaching practice is attributed to the availability of a well-defined linguistic theory that makes principled contrastive analysis actually possible. They emphasise that consciousness raising as advanced by them for the purpose of developing grammar in second language acquisition should not be seen as an alternative in any way to communicative language teaching: they consider consciousness raising as a potential facilitator for the acquisition of linguistic competence. Consciousness raising should thus be seen as part of a larger pedagogical context that includes all the other essential components for second language acquisition. Rutherford and Sharwood-Smith argue that the time has come for consciousness raising in this sense and the pedagogical grammar hypothesis to be investigated in empirical studies since with recent advances in the delineation of Universal Grammar, phenomena can be investigated in a systematic way.

Cook (1988) points out that the methodology of Universal Grammar research on second language acquisition has to take into account the apparent effects of variations in the initial state and terminal state knowledge of learners, the apparent effects of differing learner personality and experience. He states further that, as with first language acquisition, the Universal Grammar approach is concerned with one of the most central aspects in second language acquisition, but it does not deal with anything else. $\mathrm{He}$ maintains that Universal Grammar plays a central and vital part in second language learning, while conceding that there are many other parts.

In conclusion, the Universal Grammar framework can provide a strong theoretical base for research into the development of grammar in second language acquisition, in particular for explaining the properties of interlanguage, some types of errors and the avoidance of certain structures of the target language. A sound understanding of theory can enable exploratory teachers to investigate these intriguing issues and to experiment with pedagogical grammar techniques that can facilitate optimal success in second language acquisition. 


\section{BIBLIOGRAPHY}

Allwright, D. and K,M. Bailey. (1991). Focus on the language classroom: An Introduction to classroom research for language teachers. Cambridge University Press.

Canale, M. and M. Swain (1980). Theoretical bases of communicative approaches to second language teaching and testing. Applied Linguistics 1, 1-47.

Canale, M. and M. Swain. (1988). Some theories of communicative competence. $\ln$ W. Rutherford and M. Sharwood Smith (Eds.) Grammar and second language teaching: A book of readings. (pp. 61-84). Newbury House.

Chaudron, C. (1986). Second language classrooms: Research on teaching and learning. Cambridge University Press.

Chomsky, N. (1981a). Lectures on government and binding. Foris Publications.

Chomsky, N. (1981b). Principles and parameters in syntactic theory. In N. Hornstein and D. Lightfoot (Eds.), Explanation in linguistics: The logical problem of language acquisition (pp. 32-75). Longman.

Chomsky, N. (1982). Some concepts and consequences of the theory of government and binding. Linguistic Inquiry Monographs no. 6. MIT Press.

Chomsky, N. (1986a). Barriers. MIT Press.

Chomsky, N. (1986b). Knowledge of language: its nature, origin and use. Praeger.

Cook, V.J. (1988). Chomsky's Universal Grammar: an introduction. Basil Blackwell.

Day, E. and Shapson, S. (1991). Integrating formal and functional approaches to language teaching in French immersion: An experimental study. Language Learning, 41, 25-58.

Doughty, C. (1991). Second language instruction does make a difference: Evidence from an empirical study of SL relativization. Studies in Second Language Acquisition, 13, 431-469.

Ellis, R. (1985). Understanding Second language acquisition. Oxford University Press. 
Ellis, R. (1990). Instructed second language acquisition: Learning in the classroom. Basil Balckwell.

Flynn, S. (1987). A parameter-setting model of L2 acquisition: Experimental studies in anaphora. D. Reidel Publishing Company.

Flynn, S. (1988). "Nature of development in L2 Acquisition and implications for theories of language acquisition in general." In S. Flynn and W. O'Neil (Eds.) Linguistic theory and second language acquisition (pp. 76-89) Kluwer Academic Publishers.

Flynn, S. (1989). The role of the head-initial/head-final parameter in the acquisition of English relative clauses by adult Spanish and Japanese speakers. In S. Gass and J. Schachter (Eds.) Linguistic perspectives on second language acquisition (pp. 89-108). Cambridge University Press.

Flynn, S. (1990). Theory, practice and research: Strange or blissful bedfellows? In: J. Alatis (ed.) Georgetown University Round Table on Languages and Linguistics (pp. 112-122). Georgetown University Press.

Flynn, S. and B. Lust. (1990). In defense of parameter-setting in L2 acquisition: A reply to Bley-Vroman and Chaudron '90. Language Learning, 40, 419-449.

Flynn, S. and W. O'Neil (Eds.) (1988). Linguistic theory and second language acquisition. Kluwer Academic Publishers.

Liceras, J. (1986). Linguistic theory and second language acquisition: the Spanish nonnative grammar of English speakers. Gunter Narr Verlag. Tübingen.

Liceras, J. (1988). "L2 learnability: delimiting the domain of core grammar as dinstinct from marked periphery." In Flynn and O'Neil, eds.

Liceras, J. (1989). On some properties of the "pro-drop" parameter: looking for missing subjects in non-native Spanish. In S. Gass and J. Schacter (Eds.) Linguistic perspectives on second language acquisition (pp. 109-133). Cambridge University Press.

Lightbown, P. and Spada, N. (1990). Focus on form and corrective feedback in communicative language teaching. Studies in Second Language Acquisition, $12,429-448$. 
McLaughlin, B. (1987). Theories of second language learning. Edward Arnold Publishers.

Nunan, D. (1989). Designing tasks for the communicative classroom. Cambridge University Press.

Nunan, D. (1991). Methods in second language classroom-oriented research: A critical review. Studies in Sccond Language Acquisition, 13, 249-274.

Rutherford, W. and M. Sharwood Smith. (1988b). Consciousness raising and Universal Grammar. In W. Rutherford and M. Sharwood Smith (Eds.) Grammar and second language teaching: A book of rcadings. (pp. 107-116). Newbury House Publishers.

Spolsky, B. (1989). Conditions for second language learning: Introduction to a general theory. Oxford University Press.

White, L. (1985). The 'pro-drop' parameter in adult second language acquisition. Language Learning, 35, 47-62.

White, L. (1988). Universal grammar and language transfer. In J. Pankhurst, M. Sharwood Smith and P. van Buren (Eds.). Learnability and second languages: A book of readings (pp. 36-61). Foris Publications.

White, L. (1989a). The adjacency condition on case assignment: do L2 learners observe the subset Principle? In S. Gass and J. Schachter (Eds.). Linguistic perspectives on second language acquisition (pp. 134-158). Cambridge University Press.

White, L. (1989b). Universal Grammar and second language acquisition. John Benjamin.

White, L. (1990a). Second language acquisition and Universal Grammar. Studies in Second Language acquisition, 12, 121-133.

White, L. (1990b). Another look at the logical problem of foreign language learning: A reply to Bley-Vroman. Linguistic Analysis, 20, 50-63.

Yalden, J. (1987). Principles of course design for Ianguage teaching. Cambridge University Press. 


\section{APPENDIX}

\section{GENERAL SOURCES ON SECOND LANGUAGE LEARNING AND TEACHING}

Aahsen, H. (1990). The comparative study of first and second language development. Studies in Second Language Acquisition 12, 135-153.

Alatis, J. (Ed.) (1990). Georgetown University Round Table on Languages and Linguistics. Linguistics, language teaching and language acquisition: The interdepcndence of theory, practica and research. Georgetown University Press.

Alexander, L. (1990). Why teach grammar? In J. Alatis (Ed.) Georgetown University Round Table on Languages and Linguistics (pp. 377-382). Georgetown University Press.

Allen, J. (1986). "Functional-analytic course design and the variable focus curriculum. In Brumfit (ed.) The practice of communicative teaching. Pergamon Press.

Allwright, D. (1982). Observations in the language classroom. Longman.

Bachman, L. (1990a). Fundamental considerations in language testing. Oxford University Press.

Bachman, L. (1990b). Constructing measures and measuring constructs. In B. Harley, P. Allen, J. Cummins and M. Swain (Eds.). The development of second language proficiency, (pp. 26-38). Cambridge University Press.

Baker, D. (1989). Language tcsting: A critical survey and practical guide. Edward Arnold Publishers.

Beebe, L.M. (ed.). (1988). Issues in second language acquisition: Multiple perspectives. Newbury House Publishers.

Berman; R. (1987). Cognitive components of language development. In C. Wollman (Ed.) First and second language acquisition processes (pp. 3-27). Newbury House Publishers. 
Bialystok, E. (1988). Psycholinguistic dimensions of second language proficiency. In W. Rutherford and M. Sharwood Smith (Eds.), Grammar and second language teaching: A book of readings. Newbury House Publishers.

Bialystok, E. (1990). Communication strategies: A psychological analysis of secondlanguage use. Basil Blackwell.

Bley-Vroman, R. (1988). The fundamental character of foreign language learning. In W. Rutherford and $M$. Sharwood Smith (Eds.), Grammar and second language teaching: A book of readings. Newbury House.

Bley-Vroman, R. (1989). "What is the logical problem of second language learning?" In S. Gass and J. Schachter (Eds.), Linguistic perspectives on second language acquisition (pp. 41-68). Cambridge University Press.

Biey-Vromian, R. (1990). The logical problem of foreign language learning. Languistic Analysis, 20, 1-49.

Bley-Vroman, R., Felix, S., and Ioup, G. (1988). The accessibility of universal grammar in adult langrage learning. Second Language Research 4, 1-32.

Breen, M. and C.N. Candlin (1980). "The essentials of a communicative curriculum in language teaching. Applied Linguistics, 2.

Brown, J.D. (1988). Understanding research in second language learning: A teacher's guide to statistic and research design. Cambridge University Press.

Brumfit, C. (1987). "Applied linguistics and communicative language teaching." In Kaplan, Robert (Ed.). Annual Review of Applied Linguistics.

Brumfit, C. (ed.) (1986). The practice of communicative teaching. Pergamon Press.

Bugarski, R. (1987). Applied linguistics as linguistics applied. In O.M. Tomic and R.W. Shuy (Eds.) The relation of theoretical and applied linguistics (pp. 3-20). Plenum Press.

Canale, M. (1983). "From communicative competence to communicative language pedagogy." In J.C. Richards and R.W. Schmidt. (Eds.) Language and communication. Longman.

Canale, M. (1987). "The measurement of communicative Competence." In Kaplan, Robert. (Ed.) Annual Review of Applied Linguistics. 
Carrol, S. (1989). Language acquisition studies and a feasible theory of grammar. Canadian Journal of Linguistics, 34, 399-418.

Carrol, S. and J. Meisel. (1990). Universals and second language acquisition: Some comments on the state of current theory. Studies in Second Language Acquisition, 12, 201-208.

Chaudron, C. (1985). A method for examining the input/intake distinction. In S. Gass and C. Madden (Eds.) Input in second language acquisition (pp. 285-302). Newbury House publishers.

Clahsen, H. (1987). Connecting theories of language processing and (second) language acquisition. In C. Wollman (Ed.) First and second language acquisition processes (pp. 103-116).

Clahsen, H. and P. Muysken (1989). The UG paradox in L2 acquisition. Second Language Researdh 5, 1-29.

Comrie, B. (1990). Second language acquisition and language universals research. Studies in Second Language Acquisition, 12, 209-218.

Cook, V.J. (1985). "Chomsky's Universal Grammar and second language learning." Applied Linguistics, 1-18.

Crookes, G. (1989). Planning and interlanguage variation. Studies in Second Language Acquisition 11, 367-383.

Crookes, G. (1991). Second language speech production research: A methodologically oriented review. Studies in Second Language Acquisition, 13, 113-132.

Davies, A. (1990). Principles of language testing. Basil Blackwell.

Eckman, F. (1988). "Typological and parametric views of universals in second language acquisition." In Flynn and O'Neil (Eds.) Linguistic theory and second language acquisition (pp. 417-429). Kluwer Academic Press.

Ehrlich, S., P. Avery and C. Yorio (1989). Discourse structure and the negotiation of comprehensible input. Studies in Second Language Acquisition 11, 397-414.

Eliasson, S. (1987). The interrelations between theoretical and applied linguistics. In O.M. Tomic and R.W. Shuy (Eds.) The relation of theoretical and applied linguistics (pp. 21-50). Plenum Press. 
Ellis, R. (1985). Teacher-pupil interaction in second language development. In S. Gass and C. Madden (Eds.). Input in second language acquisition (pp. 69-88). Newbury House Publishers.

Ellis, R. (1989). Are classroom and naturalistic acquisition the same? A study of the classroom acquisition of German word order rules. Studies in Second Language Acquisition, 11, 305-328.

Ellis, R. (1991). Grammaticality judgments in second language acquisition. Studies in Second Language Acquisition, 13, 161-186.

Eubank L. (1989). Parameters in L2 learning: Flynn revisited. Second Language Research 5, 43-73.

Felix, S. (1988). UG-generated knowledge in adult second language acquisition." In Flynn and $O$ 'Neil (Eds.) Linguistic theory and second language acquisition (pp. 277-294). KJuwer Academic Press.

Flynn, S. (1984). Similarities and differences between first and second language acquisition: setting the parameters of universal grammar, In D. Rogers and J. Sloboda (eds.). Acquisition of symbolic skills. Plenum Press.

Fomic, O.M. and R.W. Shuy. (1987). The relation of theoretical and applied linguistics. Plenum Press.

Frazier, L. and J. de Villiers (Eds.) (1990). Language processing and language acquisition. Kluwer Academic Publishers.

Freudenstein, R. and C. Vaughan James (1986). Confidence through compctence in modern language learning. Centre for Information on Language Teaching and Research.w.

Gair, J. (1988). "Kinds of markeuness." In S. Flynn and O'Ncil (Eds.).

Garrett, N. (1990). What kind of theory? What kind of practice? What kind of research? In J. Alatis (Ed.) Georgetown University Round Table on Languages and Linguistics (pp. 514-523).

Gass, S. (1988). "Second language acquisition and linguistic theory: the role of language transfer." In S. Flynn and W. O'Neill, (Eds.). 
Gass, S. (1989). How do learners resolve linguistic conflicts? In S. Gass and J. Schachter (Eds.) Linguistic perspectives on second language acquisition (pp. 183-200). Cambridge University Press.

Gass, S. and C. Madden (Eds.) (1985). Input in second language acquisition. Newbury House Publishers.

Gass, S. and J. Schachter (Eds.). (1989). Linguistic perspectives on second language acquisition. Cambridge University Press.

Gass, S., C. Madden, D. Preston and L. Selinker (Eds) (1989). Variation in second Ianguage acquisition: Vol. 2. Psycholinguistic issues. Multilingual Matters, Clevedon.

Girard, D. (1986). "Learning to communicate in a foreign language." In Freudenstein and Vaughan Janes (Eds.) Confidence through competence in modern language learning. Centre for Information on Language Teaching and Research.

Gregg, K. (1989). Second language acquisition theory: The case for a generative perspective. In S. Gass and J. Schachter (Eds.) Linguistic Perspectives on second language acquisition (pp. 15-40). Cambridge University Press.

Grotjahn, R. (1991). The research programme subjective theories: A new approach in second language research. Studies in Second Language Acquisition, 13, 187214.

Grotjahn, R. and G. Kasper (1991). Introduction. Studies in Second Language Acquisition, 13, 109-112.

Harley, B. P. Allen, J. Cummins and M. Swain (Eds.) (1990). The development of second language proficiency. Cambridge University Press.

Harley, B., J. Cummins, M. Swain and P. Allen (1990). The nature of language proficiency. In B. Harley, P. Allen, J. Cummins and M. Swain (Eds.). The development of second language proficiency (pp. 1-25). Cambridge University Press.

Harmer, Jeremy (1987). Teaching and learning grammar. Longman.

Horwitz, E. (1987). "Linguistic and communicative competence: Reassessing foreign language aptitude." In Van Patten et. al. (Eds.) Foreign language learning: A research perspective. Newbury House Publishers. 
Howatt, A.P.R. (1987). "From structural to communicative." In Kaplan, R., ed. Annual Revicw of Applied Linguistics, Vol. 8.

Hughes, A. (1989). Testing for language teachers. Cambridge University Press.

Hurford, J.R. (1991). The evolution of the critical period for language acquisition. Cognition, 40, 159-201.

Hyams, N. (1986). Language acquisition and the theory of parameters. D. Reidel Publishers.

Hyltenstam, K. (1987). Markedness, language universals, language typology and second language acquiisition. In C. Wollman (Ed.) First and second languagc acquisition processes (pp. 55-80). Newbur House Publishers.

Jenkins, L. (1988). Second language acquisition: A biolinguistic perspective. In S. Flynn and W. O'Neil (Eds.) Linguistic theory in second language acquisition (pp. 109-116). Kluwer Academic Publishers.

Johnson, K. (1987). "Communicative teaching methodology. In Kaplan, K. ed. Annual Revicw of Applied Linguistics.

Kaplan, R. (1987) (Ed,) Annual Review of Applied Linguistics. Vol 8.

Kasper, G. and M. Dahl. (1991). Research methods in interlanguage pragmatics. Studies in Second Language Acquisition, 13, 215-247.

Klein, W. (1990). A theory of language acquisition is not so easy. Studies in Second Language Acquisition, 12, 219-231.

Larsen-Freeman, D. (1985). State of the art on input on second language acquisition. In S. Gass and C. Madden (Eds.) Input in second language acquisition (pp. 433444). Newbury House Publishers.

Larsen-Freeman, D. (1990). On the need for a theory of language teaching. In J. Alatis (Ed.). Georgetown University Round Table on Languages and Linguistics (pp. 261-270). Georgetown University Press.

Liceras, J. (1985). The role of intake in the determination of learner's competence. In S. Gass and C. Madden (Eds.) Input in second language acquisition (pp. 354376). Newbury House Publishers. 
Lightbown, P. (1986). Great expectations: Second-language acquisition research and classroom teaching. Applied Linguistics, 6, 173-189.

Lightbown, P. (1987). Classroom language as input to second language acquisition. In C. Wollman (Ed.) First and second language acquisition processes (pp. 168190). Newbury House Publishers.

Lightbown, P. (1991). What have we here? Some observations on the influence of instruction on L2 learning. In R. Phillipson, E. Kellerman, L. Selinker, M. Sharwood Smith and M. Swain (Eds.), Foreign language pedagogy research: A commemorative volume for Claus Faerch. Multilingual Matters, Clevedon.

Long, M. (1985). Input and second language acquisition theory. In S. Gass and G. Madden (Eds.). Input in second language acquisition (pp. 377-393). Newbury House.

Long, M. (1988). Instructed interlanguage development. In Beebe (Ed.). Issues in second language acquisition: Multiple perspectives (pp. 113-142). Newbury House.

Lust, B. (1988). "Universal Grammar in second language acquisition: Promises and problems in critically relating theory and empirical studies." In Flynn and O'Neil, eds.

Luukkainen, M. (1986). "Language awareness, communicative competence and testing." In Freudenstein and Vaughan James. eds.

Lyons, J. (1990). Linguistics: Theory practice and research. In J. Alatis (Ed.) Georgetown University Round Table on Languages and Linguistics (pp. 1130). Georgetown University Press.

Malamah-Thomas, A. (1987). Classroom interaction. Oxford University Press.

Maley, A. (1986). "'A rose is a rose', or is it?: can communicative competence be taught?" In Brumfit.

Mitchell, R. and R. Johnstone (1986). "The routinization of 'communicative' methodology." In Brumfit. (Ed.) The practice of communicative teaching. Pergamon Press. 
Newmeyer, F. and S. Weinberger (1988). "The ontogenesis of the field of second language research." In S. Flynn and W. O'Neil. (Eds.) Linguistic theory and second language acquisition (pp. 34-45). Kluwer Academic Publishers.

Norman, D., U. Levihn and J-A. Hedenquist (1986). Communicative ideas: an approach with classroom activities.'Language Teaching Publications, England.

O'Malley, M. (1990). The cognitive basis for second language instruction. In J. Alatis (Ed.) Georgetown University Round Table on Languages and Linguistics (pp. 478-495). Georgetown University Press.

Obler, L. (1988). Neurolinguistics and parametersetting. In S. Flynn and W. O'Neil (Eds.) Linguistic theory and second language acquisition (pp. 117-125). Kluwer Academic Publishers.

Pankhurst, J. Sharwood-Smith, M., and Van Buren, P. (Edms). (1988). Learnability and second languages: $A$ book of readings. Foris Publications.

Parkinson, B. and J. Maher (1987). "Communicative language teaching and related approaches." In Kaplan, ed. Annual Review of Applied Linguistics, 8.

Pica, T. and C. Doughty (1985). Input and interaction in the communicative language classroom: A comparison of teacher-fronted and group activities. In S. Gass and C. Madden (Eds.). Input in second language acquisition (pp. 115-136). Newbury House Publishers.

Pieneman, M. (1987). Psychological constraints on the teachability of languages. In C. Wollman (Ed.). First and second language acquisition processes (pp. 143168). Newbury House Publishers.

Pieneman, M. (1988). Psychological constraints on the teachability of language. In W. Rutherford and M. Sharwood Smith (Eds.). Grammar and second language tcaching: A book of readings. (pp. 85-106). Newbury House Publishers.

Pit Corder, S. (1988). Pedagogic grammars. In W. Rutherford and M. Sharwood Smith (Eds.). Grammar and second language teaching: A book of readings. (pp. 123-145). Newbury House.Publishers.

Prabhu, N.S. (1987). Second language pedagogy. Oxford University Press. 
Register, N. (1990). Influences of typological parameters on L2 learners' judgments of null pronouns in English. Language Learning 40, 3, 369-385.

Richards, J. (1990). Integrating theory and practice in second language teacher education: the role of action research. In J. Alatis (Ed.) Georgetown University Round Table on Languages and Linguistics (pp. 218-228). Georgetwon University Press.

Richards, J. C. and T. R. Rodgers (1986). Approaches and methods in language teaching: a description and analysis. Cambridge University Press.

Ringbom, H. (1987). The role of the first language in foreign language learning. Clevedon, Philadelphia.

Rivers, W. M. (Ed.) (1987). Interactive language teaching. Cambridge University Press.

Roeper, T. and E. Williams (Eds.) Parameter setting. D. Reidel Publishers.

Rutherford, W. (1982). "Markedness in second language acquisition." Language Learning, 32 .

Rutherford, W. (1987). Second language grammar: learning and teaching. Longman.

Rutherford, W. (1988a). Grammatical consciousness raising in brief historical perspcctive. In W. Rutherford and M. Sharwood Smith (Eds.), Grammar and second language teaching: A book of readings. Newbury House.

Rutherford, W. (1988b). Aspects of pedagogical grammar. In W. Rutherford and M. Sharwood Smith (Eds.) Grammar and secind language teaching: A book of readings (pp. 171-185).

Rutherford, W. (1988c). Functions of grammar in a language-teaching syllabus. In W. Rutherford and M. Sharwood Smith (Eds.) Grammar and second language teaching: A book of readings (pp. 231-249). Newbury House Publishers.

Rutherford, W. (1988d). "Grammatical theory and L2 Acquisition: the role of language transfer." In Flynn and O'Neil (Eds.) Linguistic theory and second language acquisition. 
Rutherford, W. (1989). Interlanguage and pragmatic word order. In S. Gass and J. Schachter (Eds.) Linguistic perspectives on second language acquisition (pp. 163-182). Cambridge University Press.

Rutherford, W. (1989). Preemption and the learning of L2 grammars. Studies in Sccond Language Acquisition, 11, 441-457.

Rutherford, W. and M. Sharwood Smith (Eds.) (1988a). Grammar and second language teaching. Newbury House.

Savignon, S (1990). Communicative language teaching: Definitions and directions. In J. Alatis (Ed.) Georgetown University Round Table on Languages and Linguistics (ppl 207-217). Georgetown University Press.

Saville-Troike, M. (1986). "From context to communication: Paths to second language acquisition." In D. Tannen (Ed.) Linguistics in context: Connecting observation and understanding.

Schachter, J. (1988). Second language acquisition and its relationship to Univcrsal Grammar. Applied Linguistics, 9, 219-235.

Schachter, J. (1989a). A new look at an old classic. Second Language Research 5, 30-42.

Schachter, J. (1989b). Testing a proposed universal. In S. Gass and J. Schachter (Eds.) Linguistic perspectives on second language acquisition (pp. 73-88). Cambridge University Press.

Schachter, J. (1990). Communicative competence revisited. In B. Harley, P. Allen, J. Cumnins and M. Swain (Eds.). The development of second language proficiency. Cambridge University Press.

Seliger, H. (1988). Psycholinguistic issues in second language acquistion. In L. Becbe (Ed.), Issues in sccond language acquisition: Multiple perspectives (pp. 1540). Newbury House.

Sharwood Smith, M. (1985). From input to intake: on argumentation in second language acquisition. In S. Gass and C. Madden (Eds.) Input in second language acquisition (pp. 394-403). Newbury House Publishers.

Sharwood Smith, M. (1986). Comprehension versus acquisition: Two ways of processing input. Applied Linguistics, 7, 239-274. 
Sharwood Smith, M. (1988a). "On the role of linguistic theory in explanations of second language devclopmental grammars." In Flynn and O’Neil, eds.

Sharwood Smith, M. (1988b). Applied linguistics and the psychology of instruction: A case for transfusion? In W. Rutherford and M. Sharwood Smith (Eds.) Grammar and Sccond language teaching: A book of readings (pp. 206-223). Newbury House Publishers.

Sharwood Smith, M. (1988c). Conciousness raising and the second language learner. In W. Rutherford and M. Sharwood Smith (Eds.) Grammar and second language teaching: A book of readings. (pp. 51-60). Newbury House.

Sharwood Smith, M. (1988d). Notions and functions in a contrastive pedagogical grammar. In W. Rutherford and M. Sharwood Smith (Eds.) Grammar and second language teaching: A book of readings (pp. 156-170). Newbury House.

Sharwood Smith, M., and Kellerman, E. (1989). The interpretation of second language output. In H.W. Dechert and M. Raupach (Eds.), Transfer in language production (pp. 217-235). Ablex Publishers.

Skehan, P. (1989). Language testing. Part II. Language Teaching, 22, 1-13.

Smith, M.J. (1988). Contemporary communication research methods. Wadsworth Publishers.

Spada, N. (1990). Observing classroom behaviours and outcomes in different second language programs. In J. Richards and D. Nunan (Eds.) Second language teacher education: Content and process. Cambridge University Press.

Spada, N. (1991). A look at the research process in classroom observation: A case study. In C. Brumfit and R. Mitchell, (Eds.), ELT Documents: Special issue on classroom centcred research. MacMillan.

Spolsky, B. (1989). "Communicative competence, language proficiency, and beyond." Applied Linguistics, 10.

Stern, H.H. (1983). Fundamental concepts in language teaching. Oxford University Press. 
Stern, H.H. (1990). Analysis and experience as variables in second language pedagogy. In B. Harley, P. Allen, J. Cunnmins, and M. Swain (Eds.). The devclopment of second language proficiency. Cambricige University Press.

Strevens, P. (1986). "Language learning and language teaching: towards an integrated model." In D. Tannen. (Ed.) Linguistics in context: Connecting observation and understanding. Ablex Publishing Corporation.

Swain, M. (1985). Communicative competence: Some roles of comprehensible input and comprehensible output in its devclopment. In S.M. Gass and C.G. Madden (Eds.) Input in Second language acquisition (pp. 235-253). Newbury House.

Swain, M. (1985). Communicative competence: some roles of comprehensible input and comprehensible output in its development. In S. Gass and C. Madden (Eds.). Input in second language acquisition (pp. 235-256). Newbury House.

Swinney, D.A. and Fodor, J.D. (1989). Introduction. Journal of Psycholinguistic Research, 18,. 1-3.

Tannen, D. (1986). Lingustics in context: connecting observation and understanding. Ablex Publishing Corporation.

Tomaselle, M. and C. Herron (1989). Feedback for language transfer errors: The garden path technique. Studies in Second Language Acquisition 11, 385-395.

Towell, R. (1987). Variability and progress in the language development of advanced learners of a foreign language. In $R$. Ellis (Ed.) Second languagc acquisition in context (pp. 113-127). Prentice Hall.

Travis, L. (1988). Linguistic theory, neurolinguistics and second language acquisition. In S. Flynn and W. O'Neil. Linguistic theory in second languagc acquisition(pp. 90-108). Kluwer Academic Publishers.

Ur, Penny (1988). Grammar practice activities: a practical guide for teachers. Cambridge University Press.

Valian, V. (1990). Logical and psychological constraints on the acquisition of syntax. In L. Fracier and J. de Villiers (Eds.) Language processing and language acquisition (pp. 119-145). Kluwer Academic Publishers.

Valian, V. (1990). Null subjects: A problem for parameter-setting models of language acquisition. Cognition, 35, 105-122. 
Van Patten, B.T.R. Dvorak and J.F. Lee (1987). Foreign language learning: a research perspective. Newbury House Publishers. Cambridge.

Weir, C. (1986). Communicative language testing with special reference to English as a foreign languagc. Exeter Linguistic Studies Vol. 11. University of Exeter.

Wexler, K. (1990). On inparsable input in language acquisition. In L. Fracier and J. de Villiers (Eds.) Language processing and language acquisition (pp. 105-117). Kluwer Academic Publishers.

Widdowson, H.G. (1986). "Design principles for a communicative grammar." In Brumfit. (Ed) The practice of communicative teaching. Pergamon Press.

Widdowson, H.G. (1989). "Knowledge of language and ability for use." Applied Linguistics. Vol. 10 no. 2.

Wollman, C. (1987) (Ed.) First and second language acquisition processes. Newbury House Publishers.

Yalden, J. (1983). The communicative syllabus: evolution, design and implementation. Pergamon Press.

Yalden, J. (1986). "An interactive approach to Syllabus design: the frameworks project." In Brufmit, ed.

Zobl, H. (1985). Grammars in search of input and intake. In S. Gass and C. Madden (Eds.) Input in second language acquisition (pp. 329-344). Newbury House Publishers.

Zobl. H. (1991). Review of L. White: Universal grammar and second language acquisition (1989). John Benjamins. Canadian Journal of Linguistics 36, 316 319. 